\title{
PENINGKATAN KETERAMPILAN GURU DALAM PENYUSUNAN RPP BERBASIS HOTS MELALUI WORKSHOP DAN PEMBIMBINGAN DI SMA NEGERI 8 PENAJAM PASER UTARA
}

\author{
Ahmad Zarkasi \\ SMAN 8 Penajam Paser Utara \\ pos-el : ahmadzarkasippu@gmail.com
}

\begin{abstract}
ABSTRAK
Tujuan penelitian (1) Untuk mendeskripsikan peningkatan keterampilan guru dalam menyusun RPP berbasis HOTS melalui model workshop dan Pembinaan, (2) penerapan konsep KKO kelompok HOTS dalam penyusunan RPP bagi guru SMA Negeri 8 Penajam Paser Utara. Metode penelitian ini penelitian action reseach class room. Penelitian menetapkan subyek guru mata pelajaran berstatus PNS 17 orang dan non PNS 4 orang. Obyek penelitian ini yakni perilaku guru dalam menyusun RPP dengan menerapkan kata kerja operasional kelompok Higher Order Tihinking Skills (HOTS) pada tujuan dan evaluasi pembelajaran di RPP. PTS dilaksanakan 2 siklus dengan masing-masing siklus dalam 2 pertemuan. Teknik pengumpulan data dengan pengadaan workshop dan ditindaklanjuti pembimbingan Kepala sekolah dalam menyusun RPP tiap mata pelajaran. Hasil penelitian pada siklus I (satu) ada 3 orang guru memperoleh peringkat sangat baik dengan data capaian masing-masing 82,00 dan 85,1. Pada siklus II (dua) terdapat perolehan capaian sangat baik berjumlah 6 guru dan 13 guru lainnya mendapat peringkat baik. Terdapat kenaikan ke jenjang baik dari peringkat cukup 7 orang yang sebelumnya ada pada siklus I (satu).Kesimpulan PTS ini menyimpulkan solusi melakukan bimbingan Kepala sekolah sebagai tindak lanjut workshop terbukti efektif karena pendekatan dialogis dan saling terbuka terjalin dalam proses bimbingan, di samping itu beberapa guru yang pernah menyusun PTK menduduki capaian sangat baik pada siklus I (satu) 3 orang dan meningkat menjadi 6 orang, sedangkan peringkat baik dari 9 orang meningkat menjadi 13 orang.
\end{abstract}

Kata kunci: keterampilan menyusun RPP HOTS, workshop dan bimbingan kepala sekolah.

\section{ABSTRACT}

Research Objectives (1) To describe the improvement of teacher skills in preparing HOTS-based RPPs through workshop and coaching models, (2) the application of the HOTS group KKO concept in the preparation of RPPs for SMA Negeri 8 Penajam Paser Utara teachers. This research method is action research class room. The study determined the subject subjects of 17 PNS and 4 non PNS. The object of this research is the teacher's behavior in preparing the lesson plan by applying the verb operational group Higher Order Tihinking Skills (HOTS) on the objectives and evaluation of learning in the lesson plan. PTS carried out 2 cycles with each cycle in 2 meetings. Data collection techniques by providing workshops and followed up with the guidance of school principals in preparing lesson plans for each subject. The results of the study in cycle I (one) there were 3 teachers who got very good ratings with achievements data of 82.00 and 85.1 respectively. In cycle II (two) there were very good achievements totaling 6 teachers and 13 other teachers received good ratings. There is an increase to a good level from the rank of 7 people who were previously in cycle I (one). Conclusion This PTS concluded that the solution to conduct the guidance of the Principal as a follow-up to the workshop proved to be effective because a dialogical and open-ended approach was intertwined in the guidance process, in addition teachers who have arranged CAR have achieved very good achievements in cycle I (one) 3 people and increased to 6 people, while the good ranking of 9 people increased to 13 people.

Keywords : skills to prepare RPS HOTS, workshop and school head guidelines. 


\section{PENDAHULUAN}

Merujuk kepada Undang-Undang Nomor 23 Tahun 2014 pasal 12 ayat 1, bahwa pendidikan termasuk urusan wajib pemerintah berkaitan dengan pelayanan dasar meliputi pendidikan anak usia dini, pendidikan dasar meliputi SD dan SMP menjadi kewenangan pemerintah Daerah. Pendidikan sekolah menengah SMA dan SMK dan pendidikan khusus menjadi kewenangan pemerintah provinsi.

Penyelenggaraan pendidikan jenjang Sekolah Menengah Atas (SMA)dan Sekolah Menengah Kejuruan merujuk pada Peraturan Menteri Pendidikan dan Kebudayaan Nomor 22 tahun 2016 tentang standar proses, pembelajaran diselenggarakan dalam rangka mencapai tujuan pendidikan nasional secara operasional tiap kegiatan pembelajaran diarahkan kepada tiga pencapaian ranah taksonomi yakni, sikap, pengetahuan dan keterampilan.

Pembelajaran sebagai wadah sarana pembentuk perilaku peserta didik, di desain oleh guru sebagai agen pembelajaran dengan menyusun Rencana Pelaksanaan Pembelajaran (RPP). Untuk menghasilkan dokumen RPP dibutuhkan pemahaman yang baik mengenai kaidah perilaku apa saja yang akan dihasilkan oleh masing-masing peserta didik dengan karakteristik unik satu dengan lainnya.

Penilaian merupakan bagian langkah penting dalam proses pembelajaran sebagai alat ukur perubahan perilaku peserta didik yang diinginkan oleh guru mengacu kepada silabus yang di sediakan oleh sekolah.

RPP sebagai rujukan silabus menggambarkan dengan jelas operasional, dalam bentuk langkah-langkah di dalam kegiatan inti pembelajaran berdasarkan standar isi dan standar kompetensi lulusan melalui proses penilaian yang ditetapkan guru mata pelajaran. Standar proses pembelajaran sebagai standar ukuran yang memandu pelaksanaan pembelajaran pendidikan di sekolah, merupakan standar nasional pendidikan berdampingan dan berisikan standar isi dan standar kompetensi lulusan.

Pelaksanaan pembelajaran yang dialogis, interaktif, dengan suasana menyenangkan menjadi daya tarik utama siswa dan guru dalam penyelenggaraan pembelajaran. Namun kondisi tersebut tidak hanya dipengaruhi oleh kurikulum, guru, peserta didik, dan sarana sekolah, tetapi kebijakan pemerintah sangat menentukan keberhasilannya.

Kebijakan pemerintah pusat yang menetapkan kurikulum sebagai acuan standar isi, proses dan kompetensi lulusan, dari aspek pengelolaannya dipindahkan dari Pemerintah Daerah Kabupaten atau Kota diserahkan kewenangannya kepada pemerintah Provisi. Proses peralihan terjadilah rekonsiliasi kebijakan semula SMA dan SMK di bawah kewenangan Pemerintah Daerah setempat, diserahkan kewenangannya ke Pemerintah Provinsi memunculkan masalah masalah baru di lingkungan SMA dan SMK.

Masalah tersebut berkenaan kondisi guru dan siswa antara lain : (1) menurunnya motivasi sebagai akibat kekosongan jalur koordinasi antara pemerintah Provinsi dan Kabupaten atau Kota. (2) keberagaman kemampuan guru SMA dan SMK yang sebelumnya di kelola oleh Pemerintah Daerah Kabupaten belum tuntas terutama dalam hal pembinaan dan kepengawasan, (3) peningkatan mutu kompetensi guru yang terputus sehingga mutu pembelajaran siswa menurun, (4) sistem koordinasi dan implementasi pembinaan dan pengawasan akademik kepada guru belum terukur, (5) masih kurangnya pembinaan guru dari internal sekolah yakni kepala sekolah. (6) Beberapa masalah tersebut di atas merupakan titik masalah krusial dalam menjamin mutu pendidikan jenjang pendidikan khususnya SMA.

Terdapat masalah-masalah krusial tersebut menuntut segera diatasi agar tidak berdampak kepada rendahnya mutu pendidikan yang lebih kompleks dan sistemik seperti : (1) Menurunnya mutu 
daya saing lulusan khususnya di SMA Negeri 8 Penajam Paser Utara. (2) Mutu daya saing dimulai dari kemampuan siswa dalam menyerap berpikir kritis terhadap tantangan masalah kehidupan siswa yang makin berat. (3) Perilaku siswa dan guru dalam pembelajaran setiap pembelajaran tidak maksimal. (4) Menurunnya implementasi pendidikan karakter siswa yang tercermin dalam sikap belajar yang cenderung menurun.

Workshop dan pembimbingan kepala sekolah dalam penyusunan Rencana Pelaksanaan Pembelajaran (RPP) berbasis HOTS merupakan langkah darurat, penting dan mendesak, karena pangkal dasar pengelolaan pembelajaran yang baik diawali dari penyusunan RPP sesuai indikator perubahan perilaku yang didinginkan yakni berbasis pada higher order thinking skill (HOTS). Keunggulan solusi workshop dan pembimbingan kepala sekolah kepada para guru sebagai langkah wajib bagi guru untuk menyusun dengan pola pengendalian program dan pendekatan konsultasi setiap saat.

Langkah memberikan pelayanan kepada guru melalui pemaparan contoh dalam pembuatan RPP kemudian guru berlatih menyusun masing-masing menurut kelompok mata pelajaran dengan pengendalian langsung internal sekolah. Kegiatan pengawasan sekaligus melekat pada tiap pelaksanaan kegiatan tanpa harus bergantung pada pihak lain. Pola ini sekaligus memainkan peran penting kepala sekolah dalam melaksanakan tugas pokok dan fungsinya yakni supervisi akademik.

Pola dan solusi mengatasi kondisi masalah di SMA Negeri 8 Penajam Paser Utara dalam upaya peningkatan mutu standar proses pembelajaran, maka judul peneltian tindakan sekolah (PTS) adalah "Peningkatan Keterampilan guru dalam penyusunan RPP berbasis HOTS melalui Workshop dan Pembimbingan di SMA Negeri 8 Penajam Paser Utara Tahun 2018/2019". a. Tujuan

Penelitian Tindakan Sekolah (PTS) bertujuan penelitian untuk mendeskripsikan peningkatan keterampilan guru dalam menyusun RPP berbasis HOTS melalui model workshop dan pembinaan di SMA Negeri 8 Penajam Paser Utara tahun 2018/2019.

1. Pemecahan masalah

Perencanaan

pembelajaran merupakan langkah untuk membuat pembelajaran bermutu, sebelum dilaksanakan oleh setiap guru mengelola pembelajarannya di kelas maupun di luar kelas. Untuk menghasilkan pembelajaran bermutu dengan menghasilkan pengalaman yang terbaik bagi seluruh peserta didik di kelas menggunakan rencana pelaksanaan pembelajaran (RPP) yang disusun oleh setiap guru. Pengalaman pembelajaran peserta didik tidak hanya kemampuan menghafal materi pembelajaran, tetapi tingkat pengalaman berpikir, seperti mampu menerapkan, menganalisis, mengevaluasi dan berkreasi tingkatan berpikir tersebut sangat dibutuhkan setiap peserta didik. Untuk menghasilkan RPP bercirikan tingkat berpikir HOTS dibutuhkan langkah seperti penyelenggaraan workshop, dan ditindaklanjuti dengan pembimbingan guru oleh Kepala SMA Negeri 8 Penajam Paser Utara. Pembimbingan itu dilaksanakan sebagai tugas pokok dan fungsinya sebagai Kepala sekolah. Pembimbingan supervisi akademik dilaksanakan dengan dua tahapan siklus.

2. Tinjuan Pustaka

Penelitian tindakan sekolah (PTS) ini merupakan penelitian implementatif yang dirancang mengacu kepada tinjauan pustaka berupa kebijakankebijakan dan teori-teori implementatif. Di antara teori-teori ini yang dirujuk tentu berdasarkan 
beberapa kata kunci judul sebagai berikut:

\section{A. Pelatihan}

Istilah pendidikan dan pelatihan sering kita dengar terasa akrab dalam kehidupan kita pada lingkungan kerja pendidikan, dua istilah pendidikan dan latihan sering di singkat keduanya menjadi DikLat. Dalam konteks PTS ini kata pelatihan merupakan kata kunci pengembangan sebagaimana pandangan Dessler (2007) dalam Casmudi dan Alipatan (2019:22) pelatihan sebagai pengembangan untuk menyiapkan karyawan dalam menghadapi pekerjaan mendatang dengan menanamkan pengetahuan, perubahan sikap atau meningkatkan keterampilan.

Hasan Basri dan Rosdiana 2015:,29 mengindikasikan bahwa kata pelatihan diambil dari aspek pengembangan kemampuan memiliki cakupan spesifik, sedangkan dari aspek area kemampuan yang menjadi penekanannya pada aspek psikomotornya, sedangkan dari aspek jangkauan waktu bersifat pendek dengan pembekalan materi bersifat khusus. Lebih lanjut menyatakan "Pelatihan kerja dirancang berdasarkan analisis kebutuhan dilakukan untuk menjawab pertanyaan apa yang harus dipelajari agar dapat menjalankan tugas dengan efektif, analisa ini digunakan sebagai dasar bagi pengembangan program pelatihan.

Pelatihan bagi guru merupakan kebutuhan yang mendasar untuk semua mata pelajaran, sebagai upaya menjembatani perubahan-perubahan lingkup tugas pokok dan fungsinya masing-masing. Perubahan yang paling esensial seperti kurikulum dari KTSP 2006 menjadi Kurikulum 2013 dan revisi Kurikulum 2013 pada tahun 2107, yang menitik beratkan standar proses pembelajaran diarahkan dari pola ranah tingkatan berpikir tingkat rendah lower order thinking skils (LOTS), menjadi higher order thinking skills (HOTS).
Pelatihan bagi guru bertujuan untuk meningkatkan pengetahuan, keterampilan guru sebagai tenaga pendidik, dan meningkatkan pengetahuan, keterampilan dalam menyiapkan administrasi pembelajaran. Suatu model pelatihan dianggap efektif manakala mampu dilandasi kurikulum, pendekatan dan strategi yang sesuai dengan kebutuhan belajar sasaran didik dan permasalahanpermasalahan yang terjadi di tengahtengahnya. Untuk itu diperlukan persyaratan khusus dalam membangun sebuah model pelatihan yang efektif dan efisien. Persyaratan tersebut di antaranya adalah kebutuhan belajar peserta pelatihan (sasaran didik, warga belajar).

Dari kondisi guru di SMA Negeri 8 Kabupaten Penajam Paser Utara, sebagian besar masih kurang mendapatkan kesempatan mengikuti pelatihan dalam meningkatkan kompetensi khususnya kompetensi pedagogik dan profesional di perlukan metode atau model pelatihan yang mampu menjamin terselenggaranya pelatihan dengan efektif, namun harus berdampak positif dari implementasinya setelah pelatihan itu diprogramkan sekolah.

Tabel 1. Alur Pelatihan Berorientasi

Peningkatan Keterampilan

\begin{tabular}{|l|l|}
\hline \multicolumn{2}{|l|}{ Pengukuran kemampuan peserta pelatihan } \\
\hline $\begin{array}{l}\text { Pengelompokan kawasan program } \\
\text { pelatihan }\end{array}$ \\
\hline \multicolumn{2}{|c|}{$\begin{array}{l}\text { Membandingkan kemampuan peserta } \\
\text { dengan materi pelatihan (belajar) }\end{array}$} \\
\hline \multicolumn{2}{|c|}{ kemampuan, } \\
\hline $\begin{array}{l}\text { Menetapkan kenjangan keman } \\
\text { keterampilan }\end{array}$ \\
\hline Mengembangkan proses pelatihan (belajar) \\
\hline \multicolumn{2}{|c|}{ (Pembelajaran) } \\
\hline Melaksanakan Pelatihan (Penelitian \\
\hline
\end{tabular}




\section{B. Pembimbingan}

Pembimbingan sebagai bagian tindak lanjut pelatihan dalam upaya meningkatkan kompetensi guru, dalam era modern guru dituntut menguasai kompetensi profesional mengikuti perkembangan ilmu pengetahuan, teknologi dan seni mutakhir, yang harus terus dikembangkan dengan belajar dan tindakan reflektif. Kompetensi profesional berkaitan dengan penguasaan materi pembelajaran secara luas dan mendalam yang meliputi konsep, struktur, metode keilmuan, teknologi seni yang menaungi materi pembelajaran (Mulyasa,2014:31).

Danim (2011) dalam Casmudi dan Alipatan (2019:24) pembinaan dan pengembangan keprofesian guru digambarkan menjadi 11 jenis kegiatan (1) aktivitas kolektif guru yang meningkatkan kompetensi dan atau keprofesian, (2) Pendidikan dan Pelatihan, (3) Pemagangan, (4) Publikasi ilmiah atas penelitian atau inovasi gagasan, (5) Karya inovatif, (6) Presensi pada forum ilmiah, (7) publikasi buku teks pelajaran yang lolos penilaian BSNP,(8) publikasi buku pengayaan, (9) publikasi buku pedoman guru, (10) Publikasi pengalaman lapangan pada pendidikan khusus dan atau pendidikan layanan khusus, (11) Penghargaan atas prestasi atau dedikasi sebagai guru yang diberikan oleh pemerintah atau pemerintah daerah.

Dari kutipan di atas pembimbingan dalam penelitian ini adalah termasuk komponen pendidikan dan pelatihan, namun hanya mengikuti pelatihan singkat saja, tujuannya untuk meningkatkan guru dalam merencanakan pembelajaran baik di kelas maupun di luar melalui penyusunan Rencana Pelaksanaan Pembelajaran (RPP) berbasis HOTS, pelatihan dan pembinaan sebagai satu langkah strategi dalam meningkatkan kompetensi pedagogik di sekolah dalam memasukkan kluster guru dalam kelompok guru profesional.

$\begin{array}{clr}\text { Menurut } & \text { Mulyasa } & (2009: 14) \\ \text { Kompetensi } & \text { profesional } & \text { adalah } \\ \text { kemampuan } & \text { penguasaan } & \text { materi }\end{array}$

pembelajaran secara luas dan mendalam yang memungkinkan membimbing peserta didik memenuhi standar kompetensi yang ditetapkan dalam Standar Nasional Pendidikan. Sedangkan secara lebih khusus, kompetensi profesional guru dapat dijabarkan sebagai berikut: (1) memahami Standar Nasional Pendidikan, (2) mengembangkan Kurikulum, menguasai materi standar, (4) mengelola program pembelajaran,(5) mengelola kelas, (6) menggunakan media dan sumber pembelajaran, (7) menguasai landasanlandasan kependidikan, (8) memahami dan melaksanakan pengembangan peserta didik, (9) memahami dan menyelenggarakan administrasi sekolah, (10) memahami penelitian dalam pembelajaran, (11) menampilkan keteladanan dan kepemimpinan dalam pembelajaran, (12) mengembangkan teori dan konsep dasar kependidikan.

Dari kutipan tersebut di atas, penelitian ini mengadopsi poin penting dalam pengembangan kurikulum terutama buku II, mengelola pembelajaran dan kelas penggunaan media dan sumber pembelajaran, memahami peserta didik tentu untuk menghasilkan penelitian pembelajaran serta menampilkan keteladanan dan kepemimpinan pembelajaran. Dari aspek-aspek tersebut di atas para guru dapat meningkatkan perencanaan pembelajarannya dalam upaya peningkatan mutu layanan pembelajaran untuk menghasilkan lulusan terbaik.

\section{Keterampilan}

Keterampilan sebagai salah satu aspek penting proses pendidikan dengan kata lain disebut psikomotorik, dalam konteks penelitian ini merujuk pada standar kompetensi lulusan (SKL) setiap sasaran pembelajaran mencakup pengembangan sikap, pengetahuan dan keterampilan. Keterampilan sebagai salah satu perubahan perilaku yang akan menghasilkan pengalaman belajar melalui 
kegiatan mengamati, menanya, mencoba, menalar, menanya, menyaji dan mencipta.

Dalam penelitian ini istilah keterampilan yang dimaksud adalah keterampilan guru dalam mengelola perencanaan pembelajaran dalam bentuk dokumen RPP bercirikan pada tingkatan berpikir tinggi dengan menggunakan istilah HOTS. Keterampilan guru ini diharapkan mampu meramu kata kerja operasional (KKO) merujuk pada Sanjaya (2007:41) dari tingkatan KKO yang dipilih oleh guru sesuai dengan tingkatan kebutuhan dan kondisi karakteristik siswa pada kelas yang diajarkan untuk dapat digunakan dalam pembelajaran sebagai standar operasional capaian pembelajaran tiap mata pelajaran.

\section{Rencana Pelaksanaan Pembelajaran (RPP)}

Menurut Mulyasa (2010) dalam Casmudi dan Alipatan (2019:82) rencana pelaksanaan pembelajaran (RPP) yang berisi selain tujuan pembelajaran juga bahan pengajaran disusun guru berdasarkan prinsip-prinsip belajar yaitu (1) bertitik tolak dari hal-hal konkret ke hal yang abstrak, (2) dikembangkan dari dari hal yang diketahui ke hal yang belum di ketahui, (3) dari pengamalan lama menjadi pengalaman baru, (4) dari hal yang mudah ke hal yang lebih sukar atau rumit.

Dari kutipan di atas, posisi penelitian ini mengambil peran seluruhnya dari 4 prinsip dalam pembelajaran, dalam merancang tujuan pembelajaran merujuk pada pilihan KKO menempatkan tingkat penerapan (C3) sebagai tumpuan HOTS yang paling rendah untuk pelaksanaan pembelajaran di SMA, untuk itu konsep yang penting diperhatikan guru merujuk pada tingkatan berpikir $\mathrm{C} 1$, dan $\mathrm{C} 2$ harus dikondisikan bahwa para siswa dinyatakan siap menguasai tingkatan berpikir itu.

Pada tingkatan berpikir Analisis, dalam kerangka KKO $\mathrm{C} 4$, menggambarkan kemampuan siswa dari C1, C2 hingga C3 tidak mengalami kesulitan sehingga kondisi belajar yang menggunakan pra syarat tingkatan berpikir mampu dilalui dengan baik. Kemampuan menggambarkan tingkatan berpikir itu membutuhkan ketelitian dan kecermatan pemahaman individual siswa.

Penyusunan KKO pada tingkatan berpikir HOTS tidak hanya cukup dilaksanakan dalam bentuk dokumen RPP, namun kajian atau telaah RPP itu benarbenar memperhatikan kondisi bobot materi, media pembelajaran, dan suasana kelas secara umumnya dalam kondisi baik. Selain harus ditelaah dengan baik tingkatan berpikir dengan pilihan $\mathrm{KKO}$ pada tujukan pembelajaran juga harus dapat dilaksanakan dengan real dan keberhasilannya dapat dipertanggung jawabkan.

Keberhasilan tujuan pembelajaran dalam RPP bercirikan HOTS tidak hanya berjalan mulus pada konteks pelaksanaan pembelajarannya, tetapi tergambar juga pada soal-soal evaluasi yang harus dikuasai oleh para siswanya di dalam kelas itu. Faktor lain yang penting diperhatikan aspek kejujuran dalam pelaksanaan pembelajaran dan waktu evaluasi dalam bentuk pelaksanaan ulangan harian maupun ulangan tengah semester dan ulangan akhir semester secara simultan tergambar kemampuan siswa dapat menjawab dan menghasilkan hasil evaluasi sesuai dengan standar KKM yang dicanangkan.

\section{Metode Penelitian}

\section{a. Prosedur}

Penelitian Tindakan Kelas (PTS) ini mengacu pada prosedur siklus penelitian tindakan merupakan penelitian tindakan maka pelaksanaan ini dilaksanakan secara siklus. Pelaksanaannya selama dua siklus. Siklus-siklus itu merupakan rangkaian yang saling berkelanjutan, maksudnya siklus kedua merupakan kelanjutan dari siklus pertama.

Langkah-langkah dalam PTS baik siklus I dan siklus II, ini terdiri dari 4 langkah yakni (a) perencanaan, 
Pelaksanaan, (c) Pengamatan, (4) Refleksi. Adapun tahap pelaksanaan perencanaan langkah-langkah konkret adalah antara lain:

\section{(1) Perencanaan}

a) Pengumpulan data awal diambil dari daftar keadaan guru untuk mengetahui pelatihan yang pernah diikuti guru, serta lamanya guru bertugas. Data awal kerja guru dan efektivitas pembelajaran dilihat dari hasil supervisi kunjungan kelas masing-masing guru sebelum dilaksanakan penelitian.

b) Mengadakan pertemuan guru-guru sebagai mitra penelitian membahas langkah-langkah pemecahan masalah perencanaan pembelajaran berbasis HOTS, dari aspek guru, dan Peneliti.

c) Merumuskan langkah-langkah tindakan yang akan dilaksanakan pada siklus pertama.

d) Model workshop dan pembimbingan guru mata pelajaran dapat meningkatkan keterampilan dalam penyusunan RPP berbasis HOTS di SMA Negeri 8 Penajam Paser Utara tahun 2018/2019.

e) Diskusi pemahaman konsep Kata Kerja operasional (KKO) untuk mampu dipahami dan diterapkan guru dalam penyusunan RPP berbasis HOTS di SMA Negeri 8 Panajam Paser Utara tahun 2018/2019.

f) Menyusun instrumen assessmen hasil kerja guru dari workshop berupa RPP berbasis HOTS.

\section{(2) Pelaksanaan}

Tahap pelaksanaan dalam penelitian tindakan sekolah (PTS) ini memiliki tiga langkah antara lain:

1) Pelaksanaan tindakan ini dilakukan oleh peneliti dimulai dari pelaksanaan workshop kepada para guru mata pelajaran dalam mencermati narasumber selama dua hari pelatihan berlangsung.

2) Mengadakan penelitian kepada guru selama membuat rencana pelaksanaan pembelajaran melalui workshop sekolah.

3) Melaksanakan supervisi akademik tentang perangkat perencanaan pelaksanaan pembelajaran berbasis HOTS.

\section{(3) Pengamatan}

Kegiatan pengamatan dalam PTS ini dilaksanakan tiap tahapan siklus kegiatan Pada prinsipnya pemantauan dilaksanakan selama penelitian berlangsung memiliki sasaran utama melihat peningkatan kemampuan guru. Adapun titik sasaran tersebut ditujukan pada hal-hal sebagai berikut:

1. Dokumen Rencana pelaksanaan pembelajaran (RPP) guru berbasis HOTS.

2. Dokumentasi RPP digunakan oleh Peneliti dalam mensupervisi guru yang akan menghasilkan catatan tiap guru dengan tingkatan sangat baik, baik, cukup dan kurang.

Adapun instrumen kunci yang digunakan peneliti dalam pengamatan adalah berdasarkan pada indikator sebagai berikut:

1) Mendeskripsikan tujuan pembelajaran

2) Tujuan pembelajaran dalam RPP memuat kata kerja operasional (KKO) pada tingkatan berpikir HOTS.

3) Tujuan pembelajaran memuat $\mathrm{KKO}$ tingkatan berpikir kognitif C3.

4) Tujuan pembelajaran memuat $\mathrm{KKO}$ tingkatan berpikir kognitif $\mathrm{C} 4$

5) Tujuan pembelajaran memuat $\mathrm{KKO}$ tingkatan berpikir kognitif C5

6) Tujuan pembelajaran memuat $\mathrm{KKO}$ tingkatan berpikir kognitif C6

7) Menetapkan materi ajar sesuai dengan indikator tingkatan $\mathrm{KD}$

8) Menentukan metode pembelajaran bercirikan pembelajaran interaktif

9) Menentukan media pembelajaran guna memperkuat pembelajaran aktif

10) Memfasilitasi sumber-sumber belajar dengan luas

11) Mencantumkan KKO ke dalam butir setiap soal bercirikan tingkatan HOTS 
12) Sebaran soal dalam RPP menggambarkan proporsional dalam tingkatan HOTS C3,C4, C5 dan C6.

\section{(4) Refleksi}

Penelitian Tindakan Sekolah (PTS) ini menggunakan refleksi sebagai tindakan menganalisis, sintesis, memaknai, menerangkan, dan akhirnya menyimpulkan semua informasi yang diperoleh dari RPP yang disusun guru. Untuk melaksanakan tahap refleksi ini Peneliti menggunakan langkah -langkah sebagai berikut:

1) Menghimpun dokumen RPP guru berbasis HOTS

2) Meneliti tiap RPP guru mata pelajaran kesesuaiannya dengan indikator tingkatan berpikir HOTS.

3) Melakukan diskusi dengan guru-guru secara terjadwal untuk membahas RPP yang disusunnya.

4) Hasil analisa dokumen tiap RPP guru mata pelajaran merujuk pada instrumen yang ditetapkan peneliti sebelumnya telah di sosialisasikan kepada mereka.

5) Menunjukkan hasil analisis dokumen kepada pemilik RPP tiap mata pelajaran pada masing-masing guru.

\section{(5) Teknik Pengumpulan data}

Penelitian Tindakan Sekolah (PTS) ini dalam teknik pengumpulan data penelitiannya adalah sebagai berikut:

a. Mengumpulkan guru dalam agenda rapat untuk melaksanakan penyusunan RPP berbasis HOTS sebagai tindak lanjut pelatihan / workshop guru di sekolah.

b. Memberikan pengarahan dan menyiapkan format dan contoh RPP berbasis HOTS.

c. Menghimpun dokumen RPP pada siklus I dan 2.

d. Menganalisis berdasarkan instrumen pada indikator kinerja PTS.

\section{(6) Teknik Analisis Data}

Penelitian Tindakan Sekolah (PTS)

ini melakukan analisis dokumen menggunakan perangkat instrumen kemudian analisis kualitatif dan kuantitatif. Analisis kualitatif digunakan untuk menjelaskan perubahan perilaku guru dari dokumen RPP berbasis HOTS yang dikumpulkan kepada peneliti melalui supervisi akademik perencanaan pembelajaran.

Penelitian tindakan sekolah(PTS) selain menggunakan analisis kualitiatif, juga menggunakan analisis kuantitatif untuk mengetahui keberhasilan guru dalam menyusun RPP berbasis HOTS merujuk Depdiknas tentang standar kompetensi guru dengan rincian sebagai berikut: sebagai berikut:

$$
\text { Nilai } 81-100=\underset{\text { berhasil. }}{\text { amat baik }(\mathrm{A})}
$$

Nilai $76-80=$ baik $(\mathrm{B})$ berhasil.

Nilai $55-75=\operatorname{cukup}(\mathrm{C})$ belum berhasil.

Nilai $0-54=$ kurang (D) belum berhasil

\section{(7) Indikator Keberhasilan}

Penelitian tindakan sekolah (PTS) ini dalam mengujur keberhasilan yang dicapai oleh peneliti dengan indikator sebagai berikut:

a. apabila angka capaian dari masingmasing guru dalam menyusun dokumen RPP berbasis HOTS memperoleh rata - rata kenaikan keseluruhan guru mata pelajaran.

b. Tolak ukur nilai keberhasilan setiap guru mata pelajaran sebesar $\geq 75$ dari penilaian dokumen RPP yang disusun kemudian dikumpulkan kepada Kepala sekolah untuk di nilai.

\section{HASIL DAN PEMBAHASAN}

Menurut data pokok pendidikan pendidikan dasar dan menengah (DAPODIK-MEN) Sejarah Singkat SMA Negeri 8 Penajam Paser Utara beralamatkan di jalan Castle Road KM 1,5 Kelurahan Nipah - Nipah Kecamatan 
Penajam, merupakan sekolah milik pemerintah daerah dengan Surat Keputusan (SK) pendirian nomor $425 / 180 / 2008$ dengan luas tanah $=40.000$ M2. akreditasi (A), pembelajaran menggunakan kurikulum 2013, kegiatan belajar mengajar selama 5 hari, hari Senin sampai Jumat. Adapun sumber pembiayaan menggunakan dana BOS dari pemerintah Provinsi Kalimantan Timur dan Pemerintah Pusat.

a. Temuan Data

1) Temuan Data Siklus I

Tabel 2. Data Temuan Capaian Guru

Penyusunan Rpp Berbasis Hots

No Kode Jumlah ISI Rata Kategori Sumer Capaia Indik -rata Capaian data $\mathrm{n}$ ator

$1 \quad$ A-1

$\begin{array}{llllll}2 & \text { B-2 } & 1018 & & 84,8 & \text { Baik } \\ 212 & 12 & 76 & \text { Baik }\end{array}$

$3 \quad$ C-3 $1021 \quad 12 \quad 85,1 \quad$ Amat

Baik

$4 \quad$ D-4 $\quad 985 \quad 12 \quad 82 \quad$ Amat

$\begin{array}{llllll}5 & \text { E-5 } & 957 & 12 & 80 & \text { Baik }\end{array}$

$\begin{array}{llllll}6 & \text { F-6 } & 914 & 12 & 76 & \text { Baik }\end{array}$

$\begin{array}{llllll}7 & \text { G-7 } & 917 & 12 & 76 & \text { Baik }\end{array}$

$8 \quad \mathrm{H}-8 \quad 902 \quad 12 \quad 75 \quad$ Cukup

$9 \quad 898 \quad 12 \quad 75 \quad$ Cukup

$\begin{array}{llllll}10 & \mathrm{~J}-10 & 889 & 12 & 74 & \text { Cukup }\end{array}$

$\begin{array}{llllll}11 & \text { K-11 } & 897 & 12 & 75 & \text { Cukup }\end{array}$

12 L-12 $915 \quad 12 \quad 76 \quad$ Baik

13 M-13 $935 \quad 12 \quad 78$ Baik

$\begin{array}{llllll}14 & \mathrm{~N}-14 & 922 & 12 & 77 & \text { Baik }\end{array}$

$\begin{array}{llllll}15 & \text { O-15 } & 929 & 12 & 77 & \text { Baik }\end{array}$

$\begin{array}{llllll}16 & \mathrm{P}-16 & 904 & 12 & 75 & \text { Baik }\end{array}$

17 Q-17 $850 \quad 12 \quad 71 \quad$ Cukup

$18 \quad \mathrm{R}-18 \quad 875 \quad 12 \quad 73 \quad$ Cukup

$\begin{array}{llllll}19 & \text { S-19 } & 901 & 12 & 75 & \text { Cukup }\end{array}$
2) Temuan Data Siklus II

Tabel 3. Data Temuan Capaian Guru

Penyusunan Rpp Berbasis Hots

\begin{tabular}{|c|c|c|c|c|c|}
\hline No & $\begin{array}{l}\text { Kode } \\
\text { Sumber } \\
\text { data }\end{array}$ & $\begin{array}{l}\text { Jumlah } \\
\text { Capaian }\end{array}$ & $\begin{array}{l}\text { ISI } \\
\text { Indikator }\end{array}$ & $\begin{array}{l}\text { Rata- } \\
\text { rata }\end{array}$ & $\begin{array}{l}\text { Kategor } \\
\text { Capaian }\end{array}$ \\
\hline 1 & A-1 & & 12 & & Amat \\
\hline & & 1068 & & 89 & Baik \\
\hline 2 & B-2 & 955 & 12 & 80 & Baik \\
\hline 3 & C-3 & 1068 & 12 & 89 & $\begin{array}{l}\text { Amat } \\
\text { Baik }\end{array}$ \\
\hline 4 & D-4 & 1021 & 12 & 85,1 & $\begin{array}{l}\text { Amat } \\
\text { Baik }\end{array}$ \\
\hline 5 & E-5 & 978 & 12 & 82 & $\begin{array}{l}\text { Amat } \\
\text { Baik }\end{array}$ \\
\hline 6 & F-6 & 925 & 12 & 77 & Baik \\
\hline 7 & G-7 & 925 & 12 & 77 & Baik \\
\hline 8 & H- 8 & 933 & 12 & 78 & Baik \\
\hline 9 & & 925 & 12 & 77 & Baik \\
\hline 10 & $\mathrm{~J}-10$ & 925 & 12 & 77 & Baik \\
\hline 11 & K-11 & 952 & 12 & 79 & Baik \\
\hline 12 & L-12 & 964 & 12 & 80 & Baik \\
\hline 13 & M-13 & 984 & 12 & 82 & $\begin{array}{l}\text { Amat } \\
\text { Baik }\end{array}$ \\
\hline 14 & $\mathrm{~N}-14$ & 964 & 12 & 80 & Baik \\
\hline 15 & O-15 & 980 & 12 & 82 & $\begin{array}{l}\text { Amat } \\
\text { Baik }\end{array}$ \\
\hline 16 & P-16 & 941 & 12 & 78 & Baik \\
\hline 17 & Q-17 & 956 & 12 & 80 & Baik \\
\hline 18 & R-18 & 956 & 12 & 80 & Baik \\
\hline 19 & S-19 & 940 & 12 & 78 & Baik \\
\hline
\end{tabular}

3) Temuan Data Analisis Siklus I dan II Tabel 4. Data Analisis Peningkatan Capaian Guru Penyusunan Rpp Berbasis Hots Kode Jumlah Jumlah Pening N Sumbe Capaian Capaian katan Ketera o r data Siklus I Siklus II Capaia ngan

$\begin{array}{lllll}1 & \text { A-1 } & 1018 & 1068 & 50 \\ 2 & \text { B-2 } & 912 & 955 & 43 \\ 3 & \text { C-3 } & 1021 & 1068 & 47 \\ 4 & \text { D-4 } & 985 & 1021 & 63 \\ 5 & \text { E-5 } & 957 & 978 & 21 \\ 6 & \text { F-6 } & 914 & 925 & 11 \\ 7 & \text { G-7 } & 917 & 925 & 8 \\ 8 & \text { H-8 } & 902 & 933 & 29 \\ 9 & & 898 & 925 & 27 \\ 10 & \text { J-10 } & 889 & 925 & 36 \\ 11 & \text { K-11 } & 897 & 952 & 55 \\ 12 & \text { L-12 } & 915 & 964 & 49 \\ 13 & \text { M-13 } & 935 & 984 & 49 \\ 14 & \text { N-14 } & 922 & 964 & 42 \\ 15 & \text { O-15 } & 929 & 980 & 31 \\ 16 & \text { P-16 } & 904 & 941 & 37 \\ 17 & \text { Q-17 } & 850 & 956 & 6 \\ 18 & \text { R-18 } & 875 & 956 & 81 \\ 19 & \text { S-19 } & 901 & 940 & 39\end{array}$




\section{b. Pembahasan}

Merujuk pada deskripsi data temuan tabel 4.1 tergambar dengan jelas, capaian tertinggi pada siklus I ada 2 orang guru memperoleh peringkat sangat baik dengan data capaian masing-masing 82,00 dan 85,1 . Terdapat : 9 orang guru memperoleh capaian baik, serta sisanya berjumlah 7 orang di antaranya memperoleh kategori cukup dengan capaian terendah;71 dan 75.

Peningkatan keterampilan tersebut terhadap guru mata pelajaran yang memperoleh kategori sangat baik karena pemahamannya dimulai dari hasil workshop penilaian HOTS yang di selenggarakan oleh pihak sekolah beberapa waktu sebelumnya. Argumentasi yang memperkuat kondisi tersebut diantaranya dua orang guru secara berkesinambungan sudah menyusun RPP HOTS dari kegiatan pembelajaran seharihari sebelum guru lainnya mengikuti supervisi perangkat pembelajaran oleh Kepala sekolah.

Kondisi guru yang mendapatkan capaian baik sebanyak 9 orang diantaranya, kelompok mata pelajaran tertentu yang secara rutin melakukan pertemuan program MGMP di sekolah, sedangkan sejumlah 7 orang guru yang memperoleh kategori cukup dari hasil pengamatan peneliti kurang aktif dari kegiatan mulai workshop penyusunan penilaian HOTS hingga pembimbingan oleh Kepala sekolah.

Catatan penting oleh Kepala sekolah ini di lakukan perbaikan sehingga pada siklus II terdapat perbedaan data yang meningkat dibanding siklus I. Keterampilan guru dalam menyusun RPP berbasis HOTS mencapai sebanyak 6 orang guru berhasil mendapatkan capaian kategori sangat baik dari siklus sebelumnya hanya 2 orang terjadi peningkatan capaian ke dalam kategori sangat baik ada 4 orang guru yang sebelumnya ada di peringkat baik. Pada kategori baik terdapat 13 orang guru dari sebelumnya 8 orang, terjadi peningkatan 5 orang guru baru yang sebelumnya berada pada posisi cukup.

Berdasarkan indikator ketercapaian keberhasilan penelitian tindakan sekolah (PTS) ini ditetapkan dengan skor nilai 81 - 100, amat baik (A) berhasil. Tujuan pembelajaran memuat $\mathrm{KKO}$ tingkat $\mathrm{C} 3$; pada siklus I sebesar 85.26 dan capaian siklus II sebesar ; 88.32 terdapat kenaikan sebesar 3,06 dengan menggunakan indikator keberhasilan sebesar ; 81-100 kategori amat baik. Tingkat keberhasilan ini tergolong peningkatan interval menengah.

Terjadinya peningkatan 3.06 menunjukkan adanya upaya guru dalam meningkatkan tingkatan berpikir dari LOTS dalam periode-periode semester sebelumnya guru kurang memperhatikan tingkatan berpikir dalam menyusun tujuan pembelajaran dalam RPP. Kenaikan sebesar 3,06 ini menunjukkan sebagian guru terus meningkatkan jenjang berpikir standar minimal C3 sebagai tingkatan berpikir paling rendah, sehingga sebagian besar guru Nampak berupaya keras mengubah platform dari C1, C2 ke C3.

\section{KESIMPULAN}

Kegiatan workshop sebagai acuan awal mengarahkan guru sekaligus titik awal menggerakkan guru menyusun RPP berbasis HOTS, yang ditindaklanjuti dalam pembinaan Kepala sekolah. Penelitian tindakan sekolah (PTS) ini menggunakan dua langkah solusi dalam upaya mengatasi masalah guru dalam menyusun RPP berbasis HOTS dilakukan Kepala sekolah dengan mengadakan workshop dan pembinaan kepada guru mata pelajaran terdapat peningkatan setelah diadakan workshop kemudian dibimbing secara berkelompok menghasilkan pada siklus I terdapat 2 guru memperoleh kategori sangat baik dan 9 orang guru kategori baik serta 7 orang diantaranya memperoleh kategori cukup.

Tindak pembimbingan Kepala sekolah menghasilkan $31,58 \%$ dari kondisi siklus I sebesar $10,53 \%$ yakni 
$21,05 \%$ kategori sangat baik. Sedangkan kategori baik terjadi peningkatan dari siklus I sebesar $42,10 \%$ dari capaian siklus 1 menjadi $68,42 \%$. Pada siklus kedua derajat kenaikan mengubah kondisi guru semula berada pada kategori cukup sebesar $36,84 \%$ berhasil meningkatkan ke kategori baik, tidak terdapat guru masuk kategori cukup atau belum berhasil.

\section{DAFTAR PUSTAKA}

Casmudi dan Alipatan, 2019, manajemen Pengembangan Kompetensi Guru, Bandung, Mujahid Press.

Mustafa, Kamal. 2003. Model-model Pelatihan, Bandung Universitas Pendidikan Indonesia.

Hasan, Basri \& Rosdiana. 2015. Manajemen Pendidikan dan Pelatihan, Bandung Pustaka Setia

Mulyasa. 2014. Pengembangan dan Implementasi Kurikulum 2013. Bandung: Remaja Rosdakarya.

Mulyasa, 2010, Menjadi Guru Profesional, Mencaiptakan Pembelajaran Kreatif dan Menyenangkan, Bandung, Remaja Rosda Karya.

Rosida 2017. Pengembangan Bahan Ajar E-Book Interaktif Untuk Menumbuhkan Keterampilan Berpikir Kritis Siswa Pada Materi Dampak Pencemaran Bagi Kehidupan, Tesis Program Pasca Sarjana IPA, Fakultas Keguruan Dan Ilmu Pendidikan Universitas Lampung Bandar Lampung

htttps://www.kemendikbud.go.id. Berbagi kewenangan pendidikan antara Pemerintah Pusat dan Daerah, 23 Nopember 2018.download, 8 Juni 2019 pukul 10.05 Wita 